\title{
Comparison of Structural Stability and Erodibility of the Purple and Loess Soils Based on Le Bissonnais Method
}

\author{
Y. Wang, Z. Wu, F.T. Li, Y. Deng, X.L. Liang $\dagger$ and G. Wang \\ College of Water Conservancy and Hydropower Engineering, Sichuan Agricultural University, Ya'an 625014, Sichuan, \\ People's Republic of China \\ $\dagger$ Corresponding author: X. L. Liang; wangyong2015@sicau.edu.cn
}

\section{Nat. Env. \& Poll. Tech. Website: www.neptjournal.com \\ Received: 07-11-2019 \\ Revised: 29-11-2019 \\ Accepted: 16-01-2020}

\section{Key Words:}

Purple soil

Loess soil

Soil aggregate

Stability index

Soil erodibility

\begin{abstract}
This paper aims to study structural differences and anti-erodibility properties of purple and loess soils in hilly terrains of southern and northern China. Yoder's method and Le Bissonnais method were used to determine the distribution of soil particle sizes, mean weight diameter (MWD), and geometric mean diameter (GMD). The sequences of water-stable aggregates in different sizes were as follows: On one hand, the sequence of purple soil aggregates was $W_{2-5 \mathrm{~mm}}>W_{0.25-0.5 \mathrm{~mm}}>W_{0.5-1 \mathrm{~mm}}>W_{0-0.053 \mathrm{~mm}}>W_{0.053-}$ $0.25 \mathrm{~mm}>W_{1-2 \mathrm{~mm}}>W_{>5 \mathrm{~mm}}$. On the other hand, the sequence of the loess soil was $W_{0-0.053 \mathrm{~mm}}>W_{0.053-}$ $0.5 \mathrm{~mm}>W_{0.25-0.5 \mathrm{~mm}}>W_{0.5-1 \mathrm{~mm}}>W_{2-5 \mathrm{~mm}}>W_{1-2 \mathrm{~mm}}>W_{>5 \mathrm{~mm}}$. Three $L B$ treatments were carried out and the results were as follows: MWD and GMD of soil aggregates in the loess soil presented the trend of slow wetting $(S W)>$ wetting stirring (WS) $>$ fast wetting $(F W)$, while those in the purple soil were WS $>S W>F W$. Under SW treatment, purple soil had higher erodibility factor $(K)$ than loess soil, close to the result of Yoder's method. Yet under WS and FW treatments, $K$ values of purple soil were much lower than that of loess soil $(P<0.05)$. A significant difference in $K$, MWD, GMD, and soil organic matter (SOM) values was found between purple soil and loess soil $(P<0.05)$. Slope positions greatly influence MWD, GMD, SOM content for the two soils $(P<0.01)$, and the interaction between soil type and slope position showed an extremely significant positive correlation to MWD and GMD $(P<0.01)$. Our study indicates that, under different breakdown mechanisms, purple soil has a more stable structure and higher anti-erodibility than loess soil. The results of this study will provide a theoretical basis for further understanding of the erosion mechanism of the main soils in China.
\end{abstract}

\section{INTRODUCTION}

Soil structure plays an important role in maintaining soil functions. The structure's basic units are soil aggregates, which will decide the stability of the soil (Mikha \& Rice 2004). Aggregate stability refers to the ability to resist external damage, which affects a variety of physical or chemical properties of the soil, such as nutrient storage, water infiltration and soil anti-erosion ability (Bernard \& Roose 2002). Improving the stability of soil aggregates will effectively enhance soil quality and prevent environmental problems such as soil erosion and other forms of land degradation (Zhu et al. 2017). Soil erodibility is the intrinsic susceptibility of a soil to erosion by runoff and raindrop impact. It is an important quantitative parameter to evaluate the sensitivity of soil to erosion. The most commonly used soil erodibility term is the soil erodibility factor $(\mathrm{K})$ of the Universal Soil Loss Equation (USLE) (Wang et al. 2014).

Purple soil is one of the most important soil resources in China. It is widely distributed in southern China and covers an area of 0.2 million $\mathrm{km}^{2}$ (about two per cent of China's territory). It is a highly fertile soil but also weatherable and prone to water erosion. Soil erosion of the purple soil in the hilly areas will result in an adverse effect on soil quality and form coarse sand, which indicates desertification (Shi et al. 2012). Most widespread in northern China, loess soil covers about 10 per cent of the land surface of the Earth and approximately 5 to 10 per cent of China's territories. Due to its special structure, loess soil has very weak resistance of soils to erosion and may be easily dislodged by heavy rains. The Loessal Plateau is one of the areas in China where soil erosion by water is problematic, which is the result of its deep loess deposits (Liu 2013).

Some studies have demonstrated the soil erosion of loess soil and purple soil by the dynamic activity of erosive agents, respectively. Others have focused on the effects of tillage, land use, and vegetation etc. (An et al. 2013, Zeng et al. 2018, Kalhoro et al. 2017, Li et al. 2015, Tuo et al. 2017, Xu et al. 2016). For example, the FW treatment of the LB method is proved to be better than Yoder's method in determining aggregate stability, especially for land uses. So, it is recommended for future studies (An et al. 2013). Furthermore, with 
the LB method, vegetation types had significant effects on soil aggregates during different rain conditions. Soil organic matter and clay contents were significantly related to the stability of soil aggregate (Zeng et al. 2018). Although external agents cause soil erosion, the structure and properties of the soil will determine how much it is eroded.

Most previous studies compared loess and purple rill erosion through measuring volume replacement (Chen et al. 2015, Chen et al. 2017, Xing et al. 2018). Yet few of them studied different soil structures and anti-erodibility in purple soil and loess soil. Therefore, the purposes of this study were (1) to compare the stability of the purple and loess soil aggregates by adopting Yoder's method and LB method, and (2) to examine soil anti-erodibility of the two soils, and discuss the similarities and differences of soil structures and anti-erodibility of purple soil and loess soil in different landscape positions.

\section{MATERIALS AND METHODS}

Soil location of this study: To further the study, we have selected two areas, of which loess soil and purple soil are widely distributed, respectively (Fig. 1). One area is located in Suining County at the centre of Sichuan Basin $\left(30^{\circ} 21^{\prime} 51^{\prime \prime}\right.$ $\left.\mathrm{N}, 105^{\circ} 28^{\prime} 37^{\prime \prime} \mathrm{E}\right)$. It is in the middle and lower reaches of the Jialing River and has the monsoon-influenced humid subtropical climate. Its annual average temperature is $18^{\circ} \mathrm{C}$ and the average annual precipitation is about $933 \mathrm{~mm}$, concentrating from May to September. Its average annual evaporation is $897 \mathrm{~mm}$. The parent material of the purple soil is the Jurassic Suining formation (J3s). Suining County is one of the main areas where purple soil is widely distributed. Located on steep slopes, most farmland is small in size and arable lands are prone to tillage erosion. The other area is located in Guyuan City of Ningxia province in China (36 $01^{\prime} 43^{\prime \prime}$ N, $106^{\circ} 28^{\prime} 08^{\prime \prime}$ E). As part of the Loessal Plateau, it is a semi-arid region in the transitional climate zone (TCZ). Its annual average temperature is $7^{\circ} \mathrm{C}$ and the average annual precipitation is about $400 \mathrm{~mm}$. Approximately $70 \%$ of annual precipitation falls as rain between June and September. The majority of the soils in the study area are loess soil. It is a result of cultivation and crop growth, which break down loessal parent material.

Soil Samples and Experimental Procedures: A straight slope was selected to study the purple soil and loess soil. It

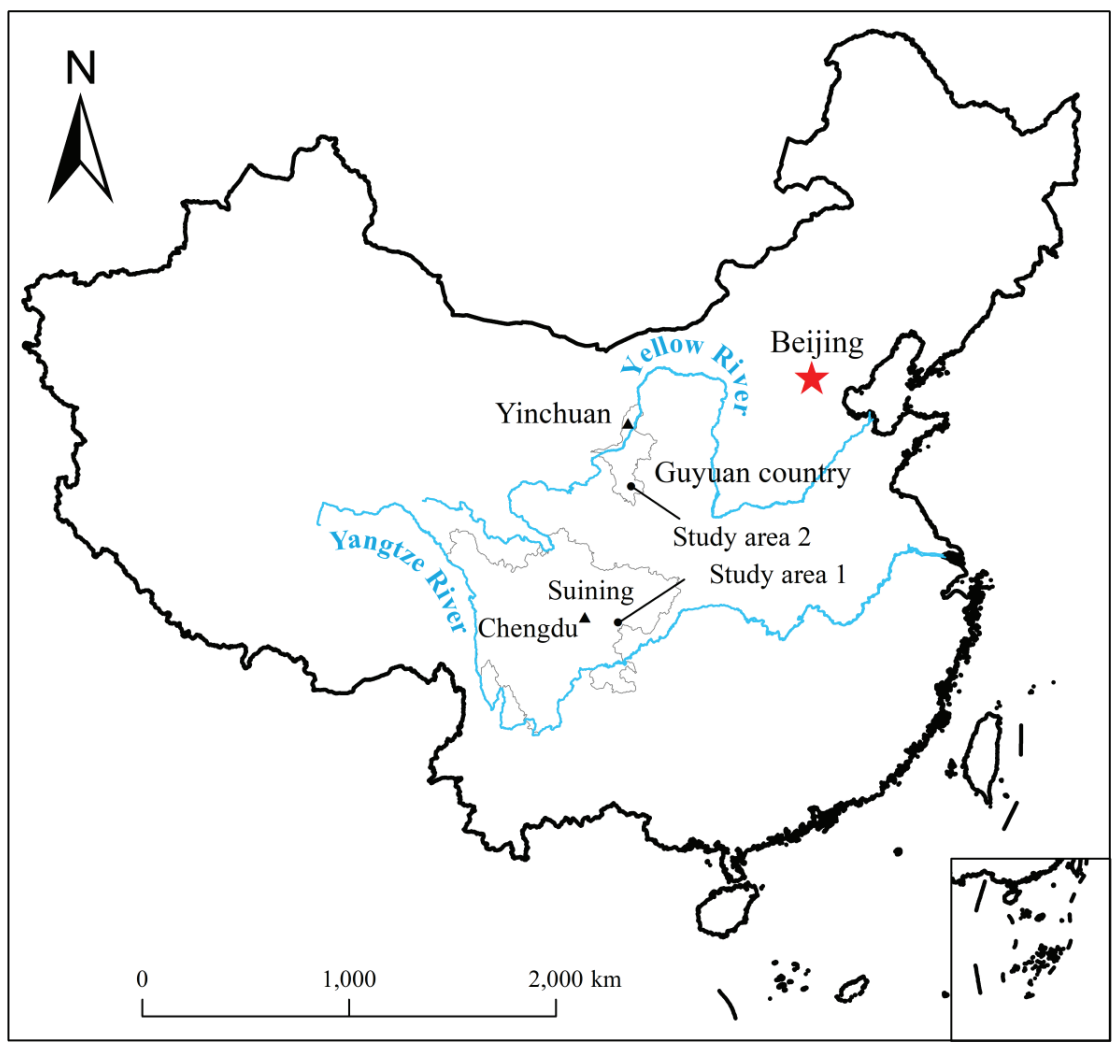

Fig. 1: Location of the study area. 
was 20 meters long and 5 meters wide, with a slope gradient of 15 degrees. The entire slope was divided into three segments: the upper $(0-7 \mathrm{~m})$, the middle $(7-14 \mathrm{~m})$, and the lower (14-20m). Five repetitions were performed to take core samples on each slope segment. For aggregate analyses, samples were collected from the surface layer $(0-20 \mathrm{~cm})$ with a flat spade, and placed in plastic containers that were rigid and impact-resistant. In this way, samples would not be disturbed during transportation to the laboratory. Subsequently, soil samples were air-dried, with large particles being gently peeled off so that the samples mainly consisted of $10-\mathrm{mm}$ diameter small clods while the natural structure of soil was preserved. Debris, roots and other impurities on the samples' surface were also removed. The distribution of aggregates' size was measured by Yoder's method and LB method.

First of all, we conducted Yoder's method, $50 \mathrm{~g}$ of aggregates was carefully added to nests of sieves, with a pan underneath, having with $5 \mathrm{~mm}, 2 \mathrm{~mm}, 1 \mathrm{~mm}, 0.5 \mathrm{~mm}, 0.25$ $\mathrm{mm}$ and $0.053 \mathrm{~mm}$ size arranged from top to bottom, respectively, on the shaker apparatus. Each sample was added to the top sieve and slowly wetted in tap water for about $20 \mathrm{~min}$. The water level in the container was adjusted to ensure that the water just touches the base of this sieve. The aggregates would be saturated due to the capillary rise. Then, the nest was manually oscillated in the water. The rate of oscillation was 60 cycles per minute and the process lasted for $2 \mathrm{~min}$. Aggregates retained in the sieves were transferred to beakers using tap water. The remained fraction on each sieve was weighed and recorded after drying at $105^{\circ} \mathrm{C}$ for $24 \mathrm{~h}$.

Secondly, we took the LB method, in which slow wetting (SW), wet stirring (WS) and fast wetting (FW) were carried out after the samples were dried at $40^{\circ} \mathrm{C}$ for $24 \mathrm{~h}$ (Bissonnais 1996). Soil aggregates with size ranging from 3 to $5 \mathrm{~mm}$ were selected to measure their structural properties. The measurements were based on the three tests FW, WS and SW. (1) FW, $5 \mathrm{~g}$ of aggregates were immersed in $50 \mathrm{~mL}$ of deionized water in a $250 \mathrm{~mL}$ beaker for 10 minutes before the water was absorbed by a liquid transfer tube. (2) WS, $5 \mathrm{~g}$ of aggregates were immersed in $50 \mathrm{~mL}$ of alcohol in $250 \mathrm{~mL}$ conical bottles (concentration 99\%). After $10 \mathrm{~min}$, water was added to $200 \mathrm{ml}$ of the conical bottle before the bottle was tightly closed with the stopper. The bottle was then carefully turned upside down for 20 times and was allowed to stand for $30 \mathrm{~min}$. It could be observed that a coarse dispersion was precipitated. A straw was used to remove the excess water. (3) SW, firstly, $5 \mathrm{~g}$ of aggregates were placed on a wet filter paper with the tension of $-0.3 \mathrm{kpa}$, and they were completely wetted for 30-40 min. Secondly, the wetted soil was moved to a screen with circular pores $50 \mu \mathrm{m}$ in diameter and was immersed in alcohol, before being swayed up and down for
20 times (the maximum extent of a vibration was $2 \mathrm{~cm}$ ). Finally, the soil was moved to an aluminium box, dried at $40^{\circ} \mathrm{C}$ and weighed. Besides, sieves with $2 \mathrm{~mm}, 1 \mathrm{~mm}, 0.5$ $\mathrm{mm}, 0.25 \mathrm{~mm}$, and $0.053 \mathrm{~mm}$ openings were used to perform dry screening for obtaining aggregates of varying sizes.

Wet oxidation with $\mathrm{K}_{2} \mathrm{Cr}_{2} \mathrm{O}_{7}$ and the pipette method (Liu 1996) were adopted to measure the concentrations of soil organic matter (SOM; g. $\mathrm{kg}^{-1}$ ) and soil particle-size fractions for each subsample. The basic soil physical and chemical properties for the purple soil and loess soil are listed in Table 1.

Calculations: Aggregate indices (MWD, mm) were calculated by:

$$
\mathrm{MWD}=\sum x_{i} \frac{m_{i}}{\sum m_{i}}
$$

Where, $x_{i}$ is the mean particle diameter of the $i^{\text {th }}$ size class (mm) and the value of $m_{i}$ is calculated from the weight of aggregates retained on each sieve $(\mathrm{g})$.

The corresponding expression of GMD ( $\mathrm{mm})$ is:

$$
\mathrm{GMD}=\exp \left\{\frac{m_{i} \ln x_{i}}{\sum m_{i}}\right\}
$$

Where, $m_{i}$ is the weight of aggregates retained on each sieve $(\mathrm{g})$ and $\ln x_{i}$ is the natural $\log$ of the average particle diameter of the $i$ th size classes $(\mathrm{mm})$.

PAD $(\%)$ is calculated as follows:

$$
\mathrm{PAD}=\frac{W_{T}-W_{S}}{W_{S}} \times 100 \%
$$

Where, $W_{T}$ refers to the weight of aggregates $>0.25 \mathrm{~mm}$ after dry sieving $(\mathrm{g})$ and $W_{S}$ indicates the weight of aggregates of the same size after wet sieving ( $\mathrm{g}$ ).

Relative slaking index (RSI) and relative mechanical breakdown index (RMI) were used to describe the breakdown mechanism of soil aggregates. Their expressions are as follows (Zhang \& Horn 2001):

$$
\begin{aligned}
\mathrm{RSI} & =\frac{\mathrm{MWD}_{\mathrm{SW}} \square \mathrm{MWD}_{\mathrm{FW}}}{\mathrm{MWD}_{\mathrm{SW}}} \\
\mathrm{RMI} & =\frac{\mathrm{MWD}_{\mathrm{SW}} \square \mathrm{MWD}_{\mathrm{WS}}}{\mathrm{MWD}_{\mathrm{SW}}}
\end{aligned}
$$

Where, $\mathrm{MWD}_{\mathrm{SW}}, \mathrm{MWD}_{\mathrm{FW}}$ and $\mathrm{MWD}_{\mathrm{Ws}}$ are the mean weight diameter values of the soils after slow wetting, fast wetting and wet stirring treatments, respectively. RSI and RMI evaluate the effects of slaking disaggregation and mechanical breakdown of soil aggregates, respectively. 
Table 1: Basic properties of soil.

\begin{tabular}{|c|c|c|c|c|c|c|c|}
\hline \multirow[t]{2}{*}{ Soil type } & \multirow{2}{*}{$\begin{array}{l}\text { Slope } \\
\text { position }\end{array}$} & \multirow{2}{*}{$\begin{array}{l}\text { Bulk Density } \\
\left(\mathrm{g} \cdot \mathrm{cm}^{-3}\right)\end{array}$} & \multirow{2}{*}{$\begin{array}{l}\text { Moisture content } \\
(\%)\end{array}$} & \multirow{2}{*}{$\begin{array}{l}\text { Organic matter } \\
\left(\mathrm{g} \cdot \mathrm{kg}^{-1}\right)\end{array}$} & \multicolumn{3}{|c|}{ Soil particle-size fraction $(\%)$} \\
\hline & & & & & $0.05-2 \mathrm{~mm}$ & $0.002-0.05 \mathrm{~mm}$ & $<0.002 \mathrm{~mm}$ \\
\hline \multirow{4}{*}{$\begin{array}{l}\text { loessal } \\
\text { soil }\end{array}$} & Upper & 1.22 & 15.21 & 4.30 & 17.91 & 69.08 & 13.01 \\
\hline & Middle & 1.11 & 15.34 & 6.77 & 17.11 & 66.18 & 16.71 \\
\hline & Lower & 1.32 & 15.16 & 9.92 & 18.79 & 67.66 & 13.56 \\
\hline & Mean & $1.22 \pm 0.09 \mathrm{~A}$ & $15.24 \pm 0.08 \mathrm{~A}$ & $9.84 \pm 1.23 \mathrm{~A}$ & $17.94 \pm 0.69 \mathrm{~A}$ & $67.64 \pm 1.18 \mathrm{~A}$ & $14.43 \pm 1.63 \mathrm{~A}$ \\
\hline \multirow{4}{*}{$\begin{array}{l}\text { purple } \\
\text { soil }\end{array}$} & Upper & 1.34 & 20.01 & 8.49 & 24.89 & 45.75 & 29.37 \\
\hline & Middle & 1.43 & 19.12 & 11.17 & 24.13 & 39.98 & 35.89 \\
\hline & Lower & 1.41 & 18.33 & 12.67 & 24.61 & 41.64 & 33.75 \\
\hline & Mean & $1.39 \pm 0.04 \mathrm{~B}$ & $19.15 \pm 0.69 \mathrm{~B}$ & $10.78 \pm 1.73 \mathrm{~A}$ & $24.54 \pm 0.31 \mathrm{~B}$ & $42.46 \pm 2.43 \mathrm{~B}$ & $33.00 \pm 2.71 \mathrm{~B}$ \\
\hline
\end{tabular}

Note: The capital letters in the same column indicate that the structural characteristics of different soils are significantly different at the level of $P<0.05$. The same below.

$K$ was calculated as follows (Shi et al. 2012):

$$
\begin{aligned}
& K= \\
& 7.954 \times\left\{0.0017+0.0494 \times \exp \left[-0.5 \times\left(\frac{\log \mathrm{GMD}+1.675}{0.6986}\right)^{2}\right]\right\}
\end{aligned}
$$

Statistical analysis: All statistical analyses were performed with SPSS (version 21.0). Duncan's multiple-range test and both One Way and Two Way ANOVA were used to analyze the significance of the differences in soil properties between the loess and purple soils. Values with the different letters indicated a significant difference $(P<0.05)$. Pearson's correlation coefficient was adopted to measure the statistical relationship between two continuous variables.

\section{RESULTS}

Properties of purple soil and loess soil in terms of soil aggregate size distribution and wet aggregate stability: The soil aggregate size distribution at different positions of the experimental terrain is shown in Fig. 2. According to Fig.

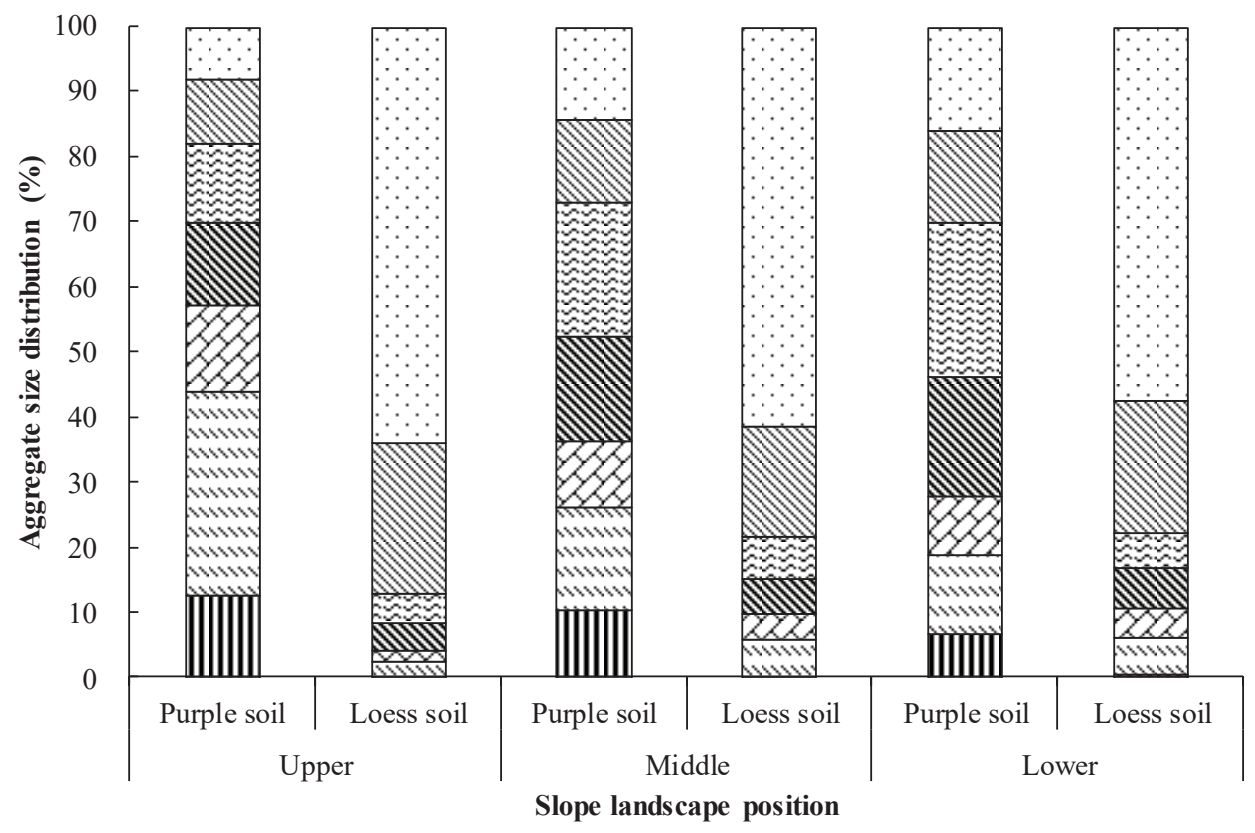

Fig. 2: Particle size distribution of purple and loess soils. 
2 , the most and second most dominant sizes of purple soil are $2 \sim 5 \mathrm{~mm}$ and $0.25 \sim 0.5 \mathrm{~mm}$, respectively. The average contents of $2 \sim 5 \mathrm{~mm}$ and $0.25 \sim 0.5 \mathrm{~mm}$ large purple soil particles are $19.68 \%(11.29 \% \sim 34.67 \%)$ and $18.76 \%$ (11.53\% 23.73\%), respectively. They are significantly higher than that of loess soil $(P<0.05,5.54 \%)$. By contrast, the dominant size of loess soil is $0 \sim 0.053 \mathrm{~mm}$, with an average content of $60.93 \%$ $(46.11 \% \sim 68.91 \%)$, significantly larger than that of purple soil $(P<0.05)$ in the same size fraction. Besides, loess soil has more $0.053 \sim 0.25 \mathrm{~mm}$ aggregates $(15.36 \% \sim 23.28 \%)$ than purple soil (less than $39.18 \%$ ). The difference between purple soil and loess soil in soil aggregate size distribution is notable. For purple soil, the contents of different particle sizes decrease in the following order: $2-5 \mathrm{~mm}>0.25-0.5 \mathrm{~mm}>$ $0.5-1 \mathrm{~mm}>0-0.053 \mathrm{~mm}>0.053-0.25 \mathrm{~mm}>1-2 \mathrm{~mm}>5 \mathrm{~mm}$. The soils at the lower slope are more stable than soils at the slope as the content of water-stable aggregates $(<0.25 \mathrm{~mm})$ increases in the slope (from top slope to foot slope). As for loess soil, the contents of different particle sizes decrease in the following order: $0-0.053 \mathrm{~mm}>0.053-0.5 \mathrm{~mm}>0.25-0.5$ $\mathrm{mm}>0.5-1 \mathrm{~mm}>2-5 \mathrm{~mm}>1-2 \mathrm{~mm}>5 \mathrm{~mm}$, among which loess soil aggregates $0-0.053 \mathrm{~mm}$ in size are most widely distributed. Based on the result of Yoder's method, there are much more water-stable aggregates in purple soil than in loess soil.

The properties of purple soil and loess soil in terms of aggregate stability based on Yoder's method and LB method: To further analyse purple and loess soils, we have used Yoder's method to determine values including MWD, GMD, PAD and the percentage of aggregates larger than 0.25 $\mathrm{mm}\left(\mathrm{R}_{0.25}\right)$ (Qi et al. 2011). The results are given in Table 2 . The MWD and GMD of purple soil were significantly higher than those of loess soil after dry sieving, indicating stronger mechanical stability of purple soil than loess soil. Moreover,
$\mathrm{R}_{0.25}$ of purple soil is three times higher than that of loess soil. Based on Yoder's method, the MWD and GMD values of purple soil were significantly higher than those of loess soil, indicating better water stability of aggregates in purple soil than in loess soil. $\mathrm{R}_{0.25}$ of purple and loess soils are significantly different. Purple soil has significantly smaller PAD value than loess soil, but both values increase as the slope goes steeper. The CV of PAD in purple and loess soils are $24.71 \%$ and $2.32 \%$ respectively. It shows that the loess soil is more easily influenced by the Yoder's method, no matter on which kind of terrain positions.

The results of the LB method show differences in MWD and GMD values among treatments (Table 3 ). After the FW treatment, different soils show significantly different MWD and GMD values, even at the same slope position. MWD and GMD of purple soil increase by $36.19 \%$ and $36.59 \%$, respectively, compared with loess soil. After the WS treatment, MWD and GMD of purple soil at the same slope position are $2.14 \mathrm{~mm}$ and $1.63 \mathrm{~mm}$, respectively, which are strikingly different with those of loess soil $(0.53 \mathrm{~mm}$ and $0.22 \mathrm{~mm})$. Despite the above-mentioned differences, $(P<0.05)$, there is no large significance between the two soils after SW treatment. The MWD values of loess soil at the same slope position show $\mathrm{SW}>\mathrm{WS}>\mathrm{FW}$, while for purple soil at the same slope position the sequence is $\mathrm{WS}>\mathrm{SW}>\mathrm{FW}$. The results of the LB (FW, SW and WS) method show that purple soil has higher aggregate stability than loess soil.

We have adopted the LB method to study the breakdown mechanism of the two types of soils and found significant differences between their soil aggregates at different terrain positions. The RSI values of purple soil are on an upward trend, while RSI values of loess soil, which are significantly higher, show a downward trend. The RMI values of loess soil are positive, and less than the RSI values. Moreover, RMI also

Table 2: The soil aggregate stability based on Yoder method.

\begin{tabular}{|c|c|c|c|c|c|c|c|c|}
\hline \multirow[t]{2}{*}{ Soil types } & \multirow{2}{*}{$\begin{array}{l}\text { Slope po- } \\
\text { sition }\end{array}$} & \multicolumn{2}{|l|}{ MWD (mm) } & \multicolumn{2}{|l|}{ GMD (mm) } & \multicolumn{2}{|l|}{$\mathrm{R}_{0.25}(\%)$} & \multirow[t]{2}{*}{ PAD (\%) } \\
\hline & & Dry & Wet & Dry & Wet & Dry & Wet & \\
\hline \multirow{4}{*}{$\begin{array}{l}\text { Loess } \\
\text { soil }\end{array}$} & Upper & 3.86 & 2.41 & 2.71 & 1.08 & 96.86 & 81.99 & 15.35 \\
\hline & Middle & 4.55 & 1.71 & 2.94 & 0.59 & 93.62 & 73.13 & 21.89 \\
\hline & Lower & 4.52 & 1.31 & 2.93 & 0.45 & 93.98 & 69.96 & 25.56 \\
\hline & Mean \pm SD & $4.31 \pm 0.32 \mathrm{~A}$ & $1.81 \pm 0.45 \mathrm{~A}$ & $2.86 \pm 0.11 \mathrm{~A}$ & $0.71 \pm 0.27 \mathrm{~A}$ & $94.82 \pm 1.44 \mathrm{~A}$ & $75.03 \pm 5.09 \mathrm{~A}$ & $20.93 \pm 4.22 \mathrm{~A}$ \\
\hline \multirow[t]{4}{*}{ Purple soil } & Upper & 0.57 & 0.22 & 0.20 & 0.06 & 19.8 & 13.09 & 31.40 \\
\hline & Middle & 0.66 & 0.37 & 0.26 & 0.08 & 33.34 & 21.59 & 31.99 \\
\hline & Lower & 0.54 & 0.41 & 0.24 & 0.09 & 32.04 & 22.36 & 32.88 \\
\hline & Mean \pm SD & $0.59 \pm 0.05 \mathrm{~B}$ & $0.33 \pm 0.08 \mathrm{~B}$ & $0.23 \pm 0.02 \mathrm{~B}$ & $0.08 \pm 0.01 \mathrm{~B}$ & $28.39 \pm 6.10 \mathrm{~B}$ & $19.01 \pm 4.20 \mathrm{~B}$ & $32.09 \pm 0.61 \mathrm{~A}$ \\
\hline
\end{tabular}


shows a downward trend. Therefore, loess soil aggregates are more prone to the slaking effect than the mechanical breakdown effect. Since the RMI values of purple soil are negative, its dominant breakdown mechanism is slaking.

The comparison of $K$ values based on Yoder method and the LB method: Yoder's method shows the significant differences between the $\mathrm{K}$ values of purple and loess soils (Fig. 3). Purple soil has much lower K values than loess soil at the same slope position. LB method studies $\mathrm{K}$ values through three treatments. It is found that the $\mathrm{K}$ values of the two soils are similar after the SW treatment. This result suggests that the dominant aggregate breakdown mechanism of purple soil is clay swelling. After the WS treatment, purple soil has much smaller $\mathrm{K}$ values than loess soil. After the FW treatment, the $\mathrm{K}$ values of loess soil increase by $102.79 \%$ compared with that of purple soil. It can be concluded that purple soil has lower erodibility than loess soil, especially for WS and FW treatment. Moreover, loess soil has higher $\mathrm{K}_{\mathrm{SW}}$ than $\mathrm{K}_{\mathrm{WS}}$ but purple soil shows the opposite pattern, which is consistent with the results of $\mathrm{MWD}_{\mathrm{SW}}$ and $\mathrm{MWD}_{\mathrm{WS}}$. In general, loess soil is more susceptible to erosion than purple soil. As for purple soil, fast wetting, among all three treatments, does the most damage to its soil aggregates, while Yoder's method has done more damage to purple soil

Table 3: The soil aggregate stability based on the LB method.

\begin{tabular}{|c|c|c|c|c|c|c|c|c|c|}
\hline \multirow{2}{*}{$\begin{array}{l}\text { Soil } \\
\text { type }\end{array}$} & \multirow{2}{*}{$\begin{array}{l}\text { Slope } \\
\text { position }\end{array}$} & \multicolumn{3}{|l|}{ MWD (mm) } & \multicolumn{3}{|l|}{ GMD (mm) } & \multirow{2}{*}{ RSI } & \multirow{2}{*}{ RMI } \\
\hline & & SW & WS & FW & SW & WS & FW & & \\
\hline \multirow{3}{*}{$\begin{array}{l}\text { Purple } \\
\text { soil }\end{array}$} & Upper & 1.53 & 2.32 & 1.18 & 0.97 & 1.85 & 0.66 & 0.23 & -0.52 \\
\hline & Middle & 0.86 & 1.63 & 0.55 & 0.49 & 1.19 & 0.26 & 0.34 & -0.91 \\
\hline & Lower & 1.35 & 2.48 & 0.72 & 0.75 & 1.84 & 0.36 & 0.48 & -0.74 \\
\hline \multirow{5}{*}{$\begin{array}{l}\text { Loess } \\
\text { soil }\end{array}$} & Mean \pm SD & $1.25 \pm 0.28 \mathrm{~A}$ & $2.14 \pm 0.37 \mathrm{~A}$ & $0.82 \pm 0.27 \mathrm{~A}$ & $0.74 \pm 0.20 \mathrm{~A}$ & $1.63 \pm 0.31 \mathrm{~A}$ & $0.43 \pm 0.17 \mathrm{~A}$ & $0.35 \pm 0.10 \mathrm{~A}$ & $-72 \pm 0.16 \mathrm{~A}$ \\
\hline & Upper & 1.93 & 0.64 & 0.59 & 1 & 0.25 & 0.22 & 0.69 & 0.65 \\
\hline & Middle & 1.15 & 0.47 & 0.38 & 0.42 & 0.19 & 0.14 & 0.67 & 0.6 \\
\hline & Lower & 1.05 & 0.5 & 0.32 & 0.47 & 0.2 & 0.13 & 0.61 & 0.48 \\
\hline & Mean \pm SD & $1.38 \pm 0.39 \mathrm{~A}$ & $0.54 \pm 0.07 \mathrm{~B}$ & $0.43 \pm 0.12 B$ & $0.63 \pm 0.26 \mathrm{~A}$ & $0.21 \pm 0.03 \mathrm{~B}$ & $0.16 \pm 0.04 \mathrm{~B}$ & $0.66 \pm 0.03 \mathrm{~B}$ & $0.58 \pm 0.07 \mathrm{~B}$ \\
\hline
\end{tabular}

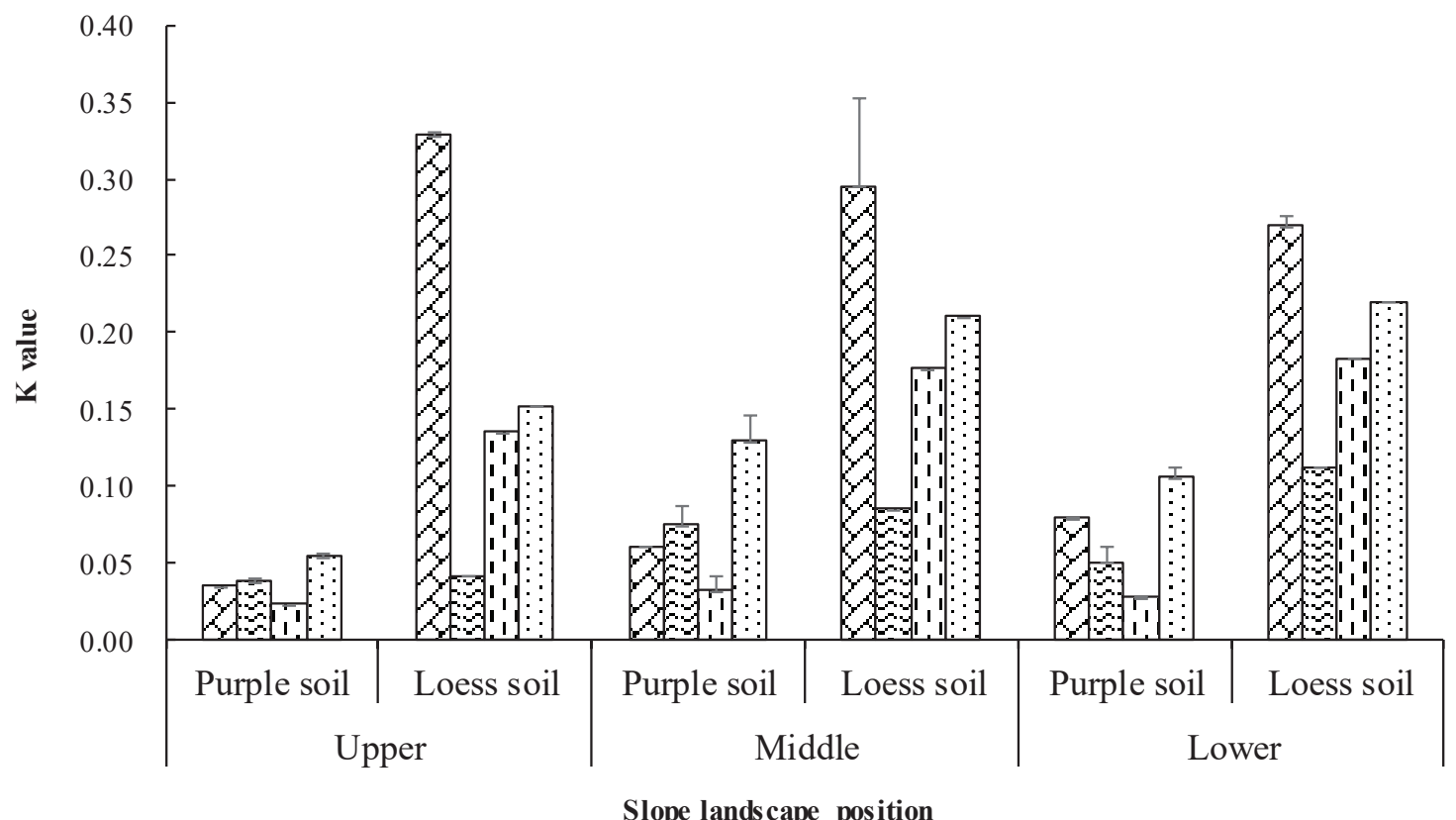

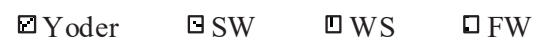

Fig. 3: Comparison of $\mathrm{K}$ values of purple soil and loess soils under different treatments. 
aggregates than the LB method. Under Yoder's method, the overall effect of the crushing mechanism is greater than the individual effect on loess soil.

Effects of slope position and soil types on the stability of soil aggregates: Table 4 gives the correlations among MWD values. In terms of purple soil, a positive and significant correlation exists between the MWD values of the SW treatment and the MWD values of the WS and FW treatments. But no such significant correlations are found in MWD values of loess soil by both Yoder's method and LB method. Purple soil shows a significant positive correlation between soil clay swelling effect and mechanical breakdown effect, and soil clay swelling effect expresses a positive relationship with slaking effect. However, no significant relationship is observed in the breakdown mechanisms of loess soil.

As findings illustrated above (Table 5), soil types greatly influence soil properties including $\mathrm{K}$ value, $\mathrm{MWD}, \mathrm{R}_{0.25}$, SOM, RSI and RMI while slope position is highly related to SOM content, MWD and GMD values. However, only MWD and GMD values show significant and positive relationship with the interaction of soil type and slope position. No significant correlation exists between SOM content and values of $\mathrm{K}, \mathrm{R}_{0.25}$, RSI and RMI. Therefore, the interaction of soil type and slope position has a significant impact on SOM.

\section{DISCUSSION}

Purple and loess soils are two typical erodible soils widely distributed in southern and northern China, respectively. They have distinct properties due to differences in climate, topography, elevation, and parent rock (Table 6). The wide difference in both latitude and topography of the two soils' geographical distribution results in different climates. Every summer, the southeast monsoon will blow from the ocean to the mainland. Monsoon also brings precipitation, the level of which decreases from east to west and from south to north. Therefore, the rainfall in the area of purple soil is $2 \sim 3$ times heavier than in the area of loess soil and often lasts for a long time. There are broad differences between the breakdown mechanism of purple and loess soils (Table 3 ).

The purple soil is weathered from purplish rocks while loess soil is a young soil that develops weakly on the loess or secondary loess parent material. Since humus accumulation and tillage fracture and crumble the soil, they disrupt soil structure, accelerating surface runoff and soil erosion. Profile of purple soil is A-AC-C. The upper and lower layers are uniform without significant difference. Leaching and precipitation are rare, and a new body is not formed. By contrast, the soil profile of loess soil is A-C; the transition of horizons is obvious; the upper and lower layers are the organic layers

Table 4: Correlation analysis of MWD values of the purple soil and loessal soil under Yoder and LB method.

\begin{tabular}{|c|c|c|c|c|c|c|c|c|}
\hline \multirow{2}{*}{ Treatment } & \multicolumn{4}{|c|}{ Purple soil } & \multicolumn{4}{|c|}{ Loess soil } \\
\hline & SW & WS & FW & Yoder & SW & WS & FW & Yoder \\
\hline SW & 1 & & & & 1 & & & \\
\hline WS & $0.831 *$ & 1 & & & 0.527 & 1 & & \\
\hline FW & $0.835^{*}$ & 0.618 & 1 & & 0.809 & 0.229 & 1 & \\
\hline Yoder & 0.336 & -0.022 & 0.708 & 1 & -0.559 & -0.772 & -0.523 & 1 \\
\hline
\end{tabular}

Notes: * Significant correlation at the $P<0.05$ level. ** Significant correlation at the $P<0.01$ level. The same below.

Table 5: Multivariate ANOVA of soil type and slope position.

\begin{tabular}{|c|c|c|c|c|c|c|}
\hline \multirow{2}{*}{ Index } & \multicolumn{2}{|c|}{ Soil type } & \multicolumn{2}{|c|}{ Slope position } & \multicolumn{2}{|c|}{ Soil type*Slope position } \\
\hline & $F$ & $P$ & $F$ & $P$ & $F$ & $P$ \\
\hline K & 152.897 & $<0.001 * *$ & 0.257 & 0.781 & 1.695 & 0.261 \\
\hline MWD & 450.398 & $<0.001 * *$ & 15.187 & $0.004 * *$ & 28.665 & $0.001 * *$ \\
\hline GMD & 2243.445 & $<0.001 * *$ & 193.636 & $<0.001 * *$ & 224.568 & $<0.001^{* *}$ \\
\hline $\mathrm{R}_{0.25}$ & 368.544 & $<0.001 * *$ & 0.183 & 0.837 & 4.934 & 0.054 \\
\hline SOM & 124.578 & $<0.001 * *$ & 69.803 & $<0.001 * *$ & 2.320 & 0.179 \\
\hline RSI & 12.059 & $0.013 *$ & 0.295 & 0.755 & 1.233 & 0.365 \\
\hline RMI & 67.841 & $<0.001 * *$ & 0.795 & 0.494 & 0.478 & 0.642 \\
\hline
\end{tabular}


Table 6: Comparison of the main properties of purple and loess soils.

\begin{tabular}{|c|c|c|}
\hline Characteristic item & Purple soil & Loess soil \\
\hline Regional distribution & $\begin{array}{l}\text { Mainly distributed in the subtropical area of China ( } \mathrm{Si}- \\
\text { chuan, Yunnan, Guizhou, etc.) and most widely distributed } \\
\text { in Sichuan Basin. }\end{array}$ & $\begin{array}{l}\text { Mainly distributed in Semi-arid and arid areas in temperate } \\
\text { and warm-wet zones (Shaanxi, Ningxia, etc.) and is the } \\
\text { most widely distributed on Loess Plateau. }\end{array}$ \\
\hline Climate condition & $\begin{array}{l}\text { The annual average temperature is } 14 \sim 18^{\circ} \mathrm{C} \text {; the annual } \\
\text { average precipitation is } 1000 \sim 1500 \mathrm{~mm} \text {; rainfalls con- } \\
\text { centrate in June-October, and the annual evaporation is } \\
300 \sim 900 \mathrm{~mm} \text {. }\end{array}$ & $\begin{array}{l}\text { The annual average temperature is } 7 \sim 16^{\circ} \mathrm{C} \text {, and the annual } \\
\text { average precipitation is } 200 \sim 500 \mathrm{~mm} \text {, mostly concentrating } \\
\text { in July-September. Annual evaporation is } 800 \sim 2200 \mathrm{~mm} \text {. }\end{array}$ \\
\hline $\begin{array}{l}\text { Mechanism } \\
\text { of soil }\end{array}$ & $\begin{array}{l}\text { Purple soil is a lithogenic soil formed by weathering of } \\
\text { purple shales in tropical and subtropical regions, mainly } \\
\text { due to frequent weathering and erosion. }\end{array}$ & $\begin{array}{l}\text { The parent material of loess is Quaternary aeolian loess. } \\
\text { Its formation is mainly through light humus accumulation } \\
\text { of grass, tillage maturation and soil erosion. }\end{array}$ \\
\hline Profile morphology & $\begin{array}{l}\text { The section structure is usually A-AC-C, with no obvious } \\
\text { humus layer. The AC transition layer is below the surface } \\
\text { layer and the parent layer is at the bottom. }\end{array}$ & $\begin{array}{l}\text { The profile is A-C soil structure, with organic stratum on } \\
\text { above and parent stratum on below. }\end{array}$ \\
\hline Topsoil properties & $\begin{array}{l}\text { The thickness of the plough layer in a farmland slope is } \\
15 \sim 20 \mathrm{~cm} \text {. Below plough layer is plough bottom layer and } \\
\text { parent material layer. }\end{array}$ & $\begin{array}{l}\text { The tillage layer is } 10 \sim 15 \mathrm{~cm} \text { thick, thinner than that of } \\
\text { purple soil, and the loess parent material layer is below } \\
\text { the tillage layer. }\end{array}$ \\
\hline Mineral composition & $\begin{array}{l}\text { The clay minerals of purple soil are mainly } 2: 1 \text { hydromica, } \\
\text { montmorillonite and chlorite. The primary minerals contain } \\
\text { a lot of quartz, and the secondary minerals are mainly illite. }\end{array}$ & $\begin{array}{l}\text { The mineral composition of loess is mainly quartz and feld- } \\
\text { spar, while the clay mineral is mainly hydromica, followed } \\
\text { by chlorite and a small amount of kaolinite. }\end{array}$ \\
\hline Architectural feature & $\begin{array}{l}\text { The pore distribution is mainly macropore }(>1.2 \mathrm{~mm}) \text {, and } \\
\text { the degree of agglomeration is high. }\end{array}$ & $\begin{array}{l}\text { Structurally loose, there are many voids between particles } \\
\text { and large voids. }\end{array}$ \\
\hline Soil particle-size fraction & $\begin{array}{l}\text { The content of sand and clay in purple soil is higher, and } \\
\text { the particles of different sizes are evenly distributed. }\end{array}$ & $\begin{array}{l}\text { The silt content of loess soil is relatively high, and the } \\
\text { particle size distribution is mainly concentrated in non-wa- } \\
\text { ter-stable aggregates. }\end{array}$ \\
\hline Chemical property & $\begin{array}{l}\text { SOM contents range from } 10 \text { to } 30 \mathrm{~g} \cdot \mathrm{kg}^{-1} \cdot \mathrm{pH} \text { is from } 5.5 \\
\text { to } 8.0 \text {, and the content of } \mathrm{CaCO}_{3} \text { is less than } 30 \mathrm{~g} \cdot \mathrm{kg}^{-1} \text {. }\end{array}$ & $\begin{array}{l}\text { SOM content is } 3 \sim 10 \mathrm{~g} \cdot \mathrm{kg}^{-1} ; \mathrm{pH} \text { is } 8.0 \sim 8.5 \text {, and the content } \\
\text { of } \mathrm{CaCO}_{3} \text { is } 90 \sim 180 \mathrm{~g} \cdot \mathrm{kg}^{-1} \text {. }\end{array}$ \\
\hline
\end{tabular}

with 10 30 cm thick; and at parent material layer, where the precipitation is greater, the calcium carbonate has been leached slightly.

Influenced by human activities, the thickness of the purple soil layer is $15 \sim 25 \mathrm{~cm}$, and the thickness of the tillage layer is relatively stable. The tillage layer of the loessal layer is about $15 \mathrm{~cm}$ thick. Some areas are less than $10 \mathrm{~cm}$ thick, and loess parent material is immediately below the tillage layer. The mineral composition of purple soil is mainly composed of hydromica and quartz. Purple soil has a stable aggregate structure, with higher contents of sand grains and clay than loess soil. The mineral composition of loess soil is mainly quartz and feldspar. Loess soil is loose in structure, with a relatively high content of silt (about 60\%). The SOM content of purple soil ranges from 10 to $30 \mathrm{~g} \cdot \mathrm{kg}^{-1}$, and the $\mathrm{pH}$ from 5.5 to 8.0, with low content of $\mathrm{CaCO}_{3}$ and very low content of nitrogen. The contents of phosphorus and potassium are rich. The SOM content of loess soil is from 3 to $10 \mathrm{~g} \cdot \mathrm{kg}^{-1}$, with the $\mathrm{pH}$ ranging from 8.0 to 8.5 , the content of $\mathrm{CaCO}_{3}$ $3 \sim 6$ times higher than that of purple soil, and low content of nitrogen, zinc, and manganese. Although loess soil is rich in phosphorus and potassium, it is hard to be made into commercial use (Li 1991, Zhang 2002).

Soil stability is greatly affected by both external and internal factors. LB method identifies different disaggregation mechanisms of soil aggregates. The SW treatment simulates the capillary action inside the soil under the damage of light rain, which causes the soil clay to swell; the WS simulates the mechanical breakdown caused by splash erosion which damages the soil structure; and the FW treatment simulates the slaking of soil under heavy rains due to gas explosion nearby. In our study, the aggregate stability of both purple soil and loess soil was most severely damaged under the FW treatment, among all three treatments. Heavy rains were the main external factor for soil erosion in the study areas, and slaking is the main internal factor of soil aggregate disruption. The SW treatment has the least damage to loess soil, which is supported by the current findings by Guo et al. (2010). The study indicates that clay swelling has little effect on the aggregate stability of loess soil. By contrast, the WS treatment has the least damage to purple soil, indicating that mechanical breakdown of splash erosion will slightly affect the aggregate stability of purple soil. In mountainous areas with purple and loess soils, serious soil erosion is observed 
in summer when heavy rains become frequent. It is recommended to plant hedgerows on the slopes to enhance soil stability and prevent soil losses (Wang et al. 2018).

Related researches showed that due to the difference in geographical location and parent material, the breakdown mechanisms of purple and loess soils were different (Wang et al. 2013). The slaking effect of loess soil was stronger than mechanical breakdown, which increased from the top to the bottom of the slope, but mechanical breakdown decreased in the opposite direction. The purple soil mainly expressed slaking rather than mechanical breakdown, because the high content of clay prevented further mechanical breakdown (Wang 2013). The high content of soil clay acted as a binder to enhance soil aggregate stability. During the wetting process, the clay enhanced the slaking and thus decreased soil aggregate stability (Yan 2008). That was the reason why the clay enhanced the stability of the agglomerate in the purple soil but reduced the stability in the loess soil. To sum up, the dissipation and mechanical effect of the LB method on loess soil is greater than that in purple soil, which affects its anti-erodibility.

There was a significant correlation between soil type and soil aggregate stability indexes. Since Yoder's method was a combination of various breakdown mechanisms, the binding effect of SOM was dwarfed by the slaking and clay swelling. As a result, the effect of SOM on soil aggregate stability became not obvious. Related researches showed that clay content significantly affected the binding effect of soil organic matter (Wang 2013). SOM promoted the stability of soil aggregates through its binding effects when the clay content was less than $25 \%$, but the effects would be lost when the clay content was above $35 \%$. According to a recent study, the MWD values of the loess soil gradually rose down the slope, while the purple soil followed the opposite trend. The clay content of purple soil was $29.37 \% \sim 35.89 \%$, and that of loess soil was $13.01 \% \sim 16.71 \%$. Therefore, SOM in loess soil promoted soil aggregate stability, but the binding effect of SOM in purple soil couldn't be reflected. Besides, as purple soil was located in a hilly area with frequent heavy rainfalls, strong water erosion occurred on the slope. Water erosion would carry the fine aggregates down the slope and caused the content of fine-grained soil at the lower slope significantly increased. Such a sorting effect on soil aggregates reduced MWD values (Zhang et al. 2014).

\section{CONCLUSION}

Laboratory experiments were conducted to evaluate structural stability and erodibility of loess and purple soils. The results of this study showed that the structural stability and erodibility of purple soil is quite different from that of loess soil. Purple soil has a more stable structure and higher anti-erodibility than loess soil under different breakdown mechanisms (SW, WS and FW). After comparing three LB treatments, we found that MWD and GMD of the loess soil showed the trend of $\mathrm{SW}>\mathrm{WS}>\mathrm{FW}$, yet that of the purple soil followed the trend of WS $>\mathrm{SW}>\mathrm{FW}$. Under the SW treatment, the $K$ value of purple soil was greater than that of loess soil and was close to the result of Yoder's method. Under WS and FW treatments, the $K$ value of the purple soil was significantly lower than that of the loess soil. This study demonstrated and provided a theoretical basis for further understanding of the erosion mechanism of the loess and purple soils in southern and northern China.

\section{ACKNOWLEDGEMENT}

This work was supported by the CRSRI Open Research Program (CKWV2018489/KY), the National Natural Science Foundation of China (41701324), and the Scientific Research Foundation of the Education Department of Sichuan Province, China (17ZB0343). Yong Wang acknowledges the China Scholarship Council for supporting a Post-Doctoral Fellow program grant (201806915001).

\section{REFERENCES}

An, S.S., Darboux, F. and Cheng, M. 2013. Revegetation as an efficient means of increasing soil aggregate stability on the Loess Plateau (China). Geoderma, 209-210: 75-85.

Bernard, B. and Roose, E. 2002. Aggregate stability as an indicator of soil susceptibility to runoff and erosion validation at several levels. Catena, 47(2): 133-149.

Bissonnais, Y.L. 1996. Aggregate stability and assessment of soil crustability and erodibility: I. Theory and methodology. European Journal of Soil Science, 47(4): 425-437.

Chen, X.Y., Huang, Y.H., Zhao, Y., Mo, B. and Mi, H.X. 2015. Comparison of loess and purple rill erosions measured with volume replacement method. Journal of Hydrology, 530: 476-483.

Chen, X.Y., Huang, Y.H., Zhao, Y., Mo, B., Mi, H.X. and Huang, C.H. 2017. Analytical method for determining rill detachment rate of purple soil as compared with that of loess soil. Journal of Hydrology, 549: 236-243.

Guo, M., Zheng, F.L., An, S.S., Liu, Y. and Darboux, F. 2010. Application of Le Bissonnais method to study soil aggregate stability in the Hilly-gully region. Science of Soil and Water Conservation, 8(2): 68-73.

Kalhoro, S., Xu, X., Chen, W., Hua, R., Raza, S. and Ding, K. 2017. Effects of different land-use systems on soil aggregates: a case study of the Loess Plateau (Northern China). Sustainability, 9(8): 1349.

Li, Z.M. 1991. Purple Soils in China. Science Press, pp. 1-122.

Li, Z.W., Zhang, G.H., Geng, R. and Wang, H. 2015. Rill erodibility as influenced by soil and land use in a small watershed of the Loess Plateau, China. Biosystems Engineering, 129: 248-257.

Liu, D.D. 2013. The coupling relationship of soil macro-structure with soil erosion resistance. Shanxi: Northwest A \& F University, pp. 1-2.

Liu, G.S. 1996. Soil Physical and Chemical Analysis and Description of Soil Profiles. Chinese Standard Press, pp. 469-517.

Mikha, M.M. and Rice, C.W. 2004. Tillage and manure effects on soil and aggregate-associated carbon and nitrogen. Soil Science Society of America Journal, 68(3): 809-816. 
Qi, Y.C., Wang, Y.Q., Liu, J., Yu, X.S. and Zhou, C.J. 2011. Comparative study on composition of soil aggregates with different land use patterns and several kinds of soil aggregates stability index. Transactions of the Chinese Society of Agricultural Engineering, 27(1): 340-347.

Shi, D.M., Chen, Z.F., Jiang, G.Y. and Jiang, D. 2012. Comparative study on estimation methods for soil erodibility K in Purple hilly area. Journal of Beijing Forestry University, 1: 32-38.

Tuo, D.F., Xu, M.X., Li, Q. and Liu, S.H. 2017. Soil aggregate stability and associated structure affected by long-term fertilization for a Loessial Soil on the Loess Plateau of China. Polish Journal of Environmental Studies, 26(3): 827-835.

Wang, B. 2013. Key factors and calculation of soil erodibility in the typical eroded black soil area of northeast China. Doctoral thesis, Northwest A \& F University, Shanxi, pp. 70-71.

Wang, J.G., Kang, Q., Kuang, G.M., Guo, Y.B. and Li, D.Q. 2014. Spatial variability of soil erodibility (K-factor) in Jianshan watershed of Yunnan province. Ecology and Environmental Sciences, 4: 555-560.

Wang, R.Z., Chen, Y., Li, T., He, B.H., Xiang, M.H., Chen, X., Tang, H., Zhou, T. and Liu, X.H. 2018. Study on stability of soil aggregates in the sedimentation zone in front of hedgerows in purple soil area. Journal of Soil and Water Conservation, 32(2): 210-216.

Wang, S.S., Huang, X.Z., Shi, D.M., Guo, Y.J. and Li, Y.X. 2013. Study on soil aggregates stability of mulberry ridge in Rocky Desertification based on Le Bissonnais method. Acta Ecologica Sinica, 33(18): 5589-5598.

Xing, H., Huang, Y.H., Chen, X.Y., Luo, B.L. and Mi, H.X. 2018. Comparative study of soil erodibility and critical shear stress between loess and purple soils. Journal of Hydrology, 558: 625-631.

Xu, M.X., Li, Q. and Wilson, G. 2016. Degradation of soil physicochemical quality by ephemeral gully erosion on sloping cropland of the hilly Loess Plateau, China. Soil and Tillage Research, 155: 9-18.

Yan, F.L. 2008. Aggregate stability characteristic of red soils and its effects on erosion processes at hillslope. Doctoral Thesis, Huazhong Agricultural University, Hubei, pp. 56-57.

Zeng, Q.C., Darboux, F., Man, C., Zhu, Z. and An, S. 2018. Soil aggregate stability under different rain conditions for three vegetation types on the Loess Plateau (China). Catena, 167: 276-283.

Zhang, B. and Horn, R. 2001. Mechanisms of aggregate stabilization in Ultisols from subtropical China. Geoderma, 99(1-2): 123-145.

Zhang, F.R. 2002. Soil Geography. China Agricultural Press, pp. 234-243.

Zhang, J.H., Wang, Y. and Zhang, Z.H. 2014. Effect of terrace forms on water and tillage erosion on a hilly landscape in the Yangtze River Basin, China. Geomorphology, 216: 114-124.

Zhu, G.Y., Shangguan, Z.P. and Deng, L. 2017. Soil aggregate stability and aggregate-associated carbon and nitrogen in natural restoration grassland and Chinese red pine plantation on the Loess Plateau. Catena, 149: 253-260. 